\title{
Analysis of pollution of soils with completed cleaning agents from individual farms growing cows, sheep and goats
}

Zhukorskyi O. ${ }^{1}$, Kryvokhyzha Ye. ${ }^{2}$, Lesyk $0 .^{3}$

${ }^{1}$ National academy of agrarian sciences of Ukraine, Mykhailo Omelianovych-Pavlenko Str., 9, Kyiv, 1010, Ukraine; ${ }^{2}$ Institute of agroecology and natural management of NAAS, Metrolohichna Str., 12, Kyiv, 143, Ukraine; ${ }^{3}$ Bukovyna state agricultural experimental station of NAAS, Bohdan Kryzhanivskyi Str., 1a, Chernivtsi, 58026, Ukraine; e-mail: 10_zhukorskiy@ukr.net, ${ }^{2}$ ye.kryvokhyzha@ukr.net, ${ }^{3}$ buksaes@meta.ua

The purpose. To analyze volumes of pollution of soils with completed acting matters of cleaning agents from individual farms growing cows, sheep and goats. Methods. Calculated method. Results. By interrogation and under the formula developed by authors volumes of receipt in soil of spent solutions of some washing and sanitizer means which are usually used in domestic economies are specified. Conclusions. It is determined that after sanitization of milking apparatuses and milk utensils in equipments of population of Ternopil, Ivano-Frankivsk and Chernivtsi oblasts the following volumes (during a year) of cleaning and sanitizing means enter the soil: surfactants $-571,6$ tons; joints of chlorine $-109,7$ tons. That can negatively influence ecosystems.

Key words: cleaning agent, sanitization, milk utensils, soil pollution, ecosystem.

Problem. Milk and dairy products are the most sought after segment of the food market. Last few years, the main producers of milk remain peasant farms. From January to October 2017, the share of households accounted for $73.9 \%$ of the total volume of milk produced in all categories of farms [1]. In these farms, mainly, manual milking of cows in milk pails, use milking machines more rarely. Save milk in the glass jars.

The receipt of milk raw with the high microbiological quality indicators is possible only with the proper sanitizing treatment of milking machines and milk containers [2, 3].

Most cleaning and disinfecting agents applied in private farms contain SAS and active chlorine [4]. SAS once released into the environment negatively influence on her state [5]. Formed by the release of active chlorine, stable organic halogen compounds (dioxins) have carcinogenic, mutagenic and teratogenic properties. Chlorinecontaining products have a strong irritant effect [6]. Therefore the analysis of the volumes emission of spent cleaning and disinfecting agents for the sanitizing of milking and diary equipment is relevant and necessary.

Analysis of recent researches and publications. The questions of safety of cleaning and disinfecting agents for people and environment is highlighted in researches of such scientists as: O.A. Bobylova [5], H. Lal [7], P.D. Abel [8], A. Azizullah [9], S. Gheorghe [10], C. Boillot [11], E. Emmanuel [12] and others. However, in the scientific literature there is no data on the determination of the volumes emission of waste cleaning agents into the environment.

The purpose of research. Carrying out analysis of volumes of soils contamination spent chemical active substances cleaning agents by private farms with raising cows, sheep and goats.

Material and methods of research. Determination of the volume of the intake chemical active substances spent of solutions cleaning and disinfecting agents into the soil after the sanitizing of milking machines and milk containers in private farms was conducted by asking and according to a formula:

$$
m=a \times \frac{(k \times d)}{100} \times e \times l
$$

where:

$\mathrm{m}$ - the quantity of chemicals active substances of spent cleaning and disinfecting agents after the sanitizing of milking machines and milk containers in private farms, $\mathrm{g}$;

a - the number of dairy cows, sheep or goats, heads; 
$\mathrm{k}$ - the average quantity of cleaning and disinfecting agent from the calculation of the use on one head, $\mathrm{g}$;

$\mathrm{d}-$ the quantity of separate active substance of cleaning and disinfecting agent, $\mathrm{g}$;

$\mathrm{e}-$ the number of sanitary processings a day;

I- duration of sanitary processings (taking into account duration of lactation), days.

The main material. The evaluation of the trend of using of cleaning and disinfecting agents conducted by questioning the members of families 408 private farms Ternopil, Ivano-Frankivsk and Chernivtsi regions with a total 238 cows and 264 sheep and goats in the period from 2015 to 2017. Results of the survey are shown in the Table 1.

\section{Results of the survey (2015-2017)}

\begin{tabular}{|c|c|c|c|}
\hline Content of the question & The response options & The quantity & $\%$ \\
\hline \multirow{7}{*}{$\begin{array}{l}\text { What kind of cleaning agent do you } \\
\text { use? }\end{array}$} & a) GALA for dishes & $\frac{48}{39}$ & $\frac{22,7}{19,8}$ \\
\hline & б) FAIRY juicy lemon & $\frac{37}{32}$ & $\frac{17,5}{16,2}$ \\
\hline & B) Pur Balsam & $\underline{35}$ & $\frac{16,6}{-}$ \\
\hline & г) Pur Power Lemon & $\overline{\overline{2}} 4$ & $\overline{\overline{1}} 2,2$ \\
\hline & д) soda ash & $\frac{30}{27}$ & $\frac{14,2}{13,7}$ \\
\hline & e) Chystyunya Lemon & $\underline{19}$ & $\frac{9,0}{-}$ \\
\hline & €) Lemon Fresh & $\overline{\overline{2}} 1$ & $\overline{\overline{1}} 0,7$ \\
\hline
\end{tabular}

Note: numerator - information from private farms with raising cows; denominator - information from private farms with raising sheep and goats.

Table 1. Continuation

\begin{tabular}{|c|c|c|c|}
\hline Content of the question & The response options & The quantity & $\%$ \\
\hline \multirow{7}{*}{$\begin{array}{l}\text { What kind of cleaning agent do you } \\
\text { use? }\end{array}$} & ж) Origami Golden & $\overline{\overline{1}} \overline{ }$ & $\overline{\overline{8}}, 6$ \\
\hline & 3) Neochlor & $\frac{16}{-}$ & $\frac{7,6}{-}$ \\
\hline & и) Novochlor-Ekstra & $\overline{\overline{7}}$ & $\overline{\overline{3}}, 6$ \\
\hline & i) mustard powder & $\frac{12}{14}$ & $\frac{5,7}{7,1}$ \\
\hline & $\begin{array}{l}\text { İ) washing with water without adding } \\
\text { cleaning agent }\end{array}$ & $\frac{9}{12}$ & $\frac{4,3}{6,1}$ \\
\hline & й) Chlorantoyin & $\underline{5}$ & $\frac{2,4}{-}$ \\
\hline & к) Dezactine & $\overline{\overline{4}}$ & $\overline{\overline{2}}, 0$ \\
\hline
\end{tabular}

Note: numerator - information from private farms with raising cows; denominator - information from private farms with raising sheep and goats.

The most widespread agents in these regions were GALA for dishes, FAIRY juicy lemon, Pur Balsam, Pur Power Lemon and soda ash, which use anymore $60.0 \%$ of private farms interviewed.

Instructions for the use of cleaning agents are examined, in particular, GALA for dishes, FAIRY juicy lemon, Pur Balsam, Pur Power Lemon, Chystyunya Lemon, Lemon Fresh, Origami Golden and also disinfecting agents: Neochlor, Novochlor-Ekstra, Chlorantoyin and Dezactine. The results of analyses of the quantitative content of their active substances are given in Table 2 .

In cleaning agents GALA for dishes, FAIRY juicy lemon, Pur Balsam, Pur Power Lemon, Chystyunya Lemon, Lemon Fresh, Origami Golden of anion, non-ionogenic and amphoteric SAS on average $68.2 \%, 24.1 \%$ and $7.8 \%$ 
respectively. The main active substances of Neochlor and Novochlor-Ekstra are inorganic compounds of chlorine. In agents of Chlorantoyin and Dezactine the percentage of organic chlorine compounds $-90.0 \%$ and anion SAS $10.1 \%$.

Taking into account the percent of the use of cleaning and disinfecting agents by interviewed private farms, the content of the active substance, concentration of working solutions and quantity processing in a year, we calculated the intake spent of agents after the sanitizing of milking machines and milk containers in soils (Figure 1).

\section{Content of active substances of cleaning and disinfecting agents used in private farms}

\begin{tabular}{|c|c|c|c|c|c|c|}
\hline \multirow[b]{2}{*}{ Name of the agent } & \multirow[b]{2}{*}{ 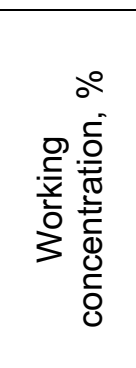 } & \multicolumn{5}{|c|}{ Quantitative content of components, \% } \\
\hline & & 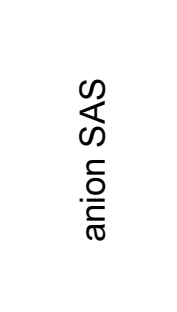 & 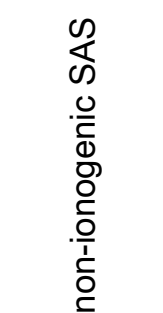 & 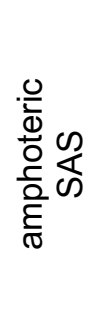 & 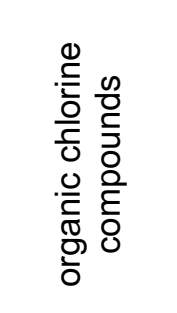 & 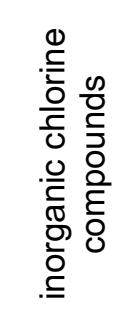 \\
\hline GALA for dishes & $0,3-0,5$ & $5,0-15,0$ & 5,0 & - & & - \\
\hline FAIRY juicy lemon & $0,2-0,3$ & $15,0-30,0$ & $5,0-15,0$ & - & - & - \\
\hline Pur Balsam & $0,3-0,5$ & $5,0-15,0$ & - & 5,0 & & - \\
\hline Pur Power Lemon & $0,3-0,5$ & $5,0-15,0$ & - & 5,0 & & $\begin{array}{ll}- \\
-\end{array}$ \\
\hline Chystyunya Lemon & $0,3-0,5$ & $5,0-15,0$ & 5,0 & - & & $\begin{array}{ll}- \\
\end{array}$ \\
\hline Lemon Fresh & $0,3-0,5$ & $5,0-15,0$ & 5,0 & - & & - \\
\hline Origami Golden & $0,3-0,5$ & 15,0 & 5,0 & 5,0 & - & - \\
\hline Neochlor & $0,5-1,0$ & - & - & - & & $7,0-9,0$ \\
\hline Novochlor-Ekstra & $0,5-1,0$ & - & - & - & - & $7,0-9,0$ \\
\hline Chlorantoyin & $0,1-0,2$ & $3,2-5,0$ & - & - & $34,0-40,0$ & - \\
\hline Dezactine & $0,1-0,2$ & $3,2-5,0$ & - & - & $33,4-39,4$ & - \\
\hline
\end{tabular}

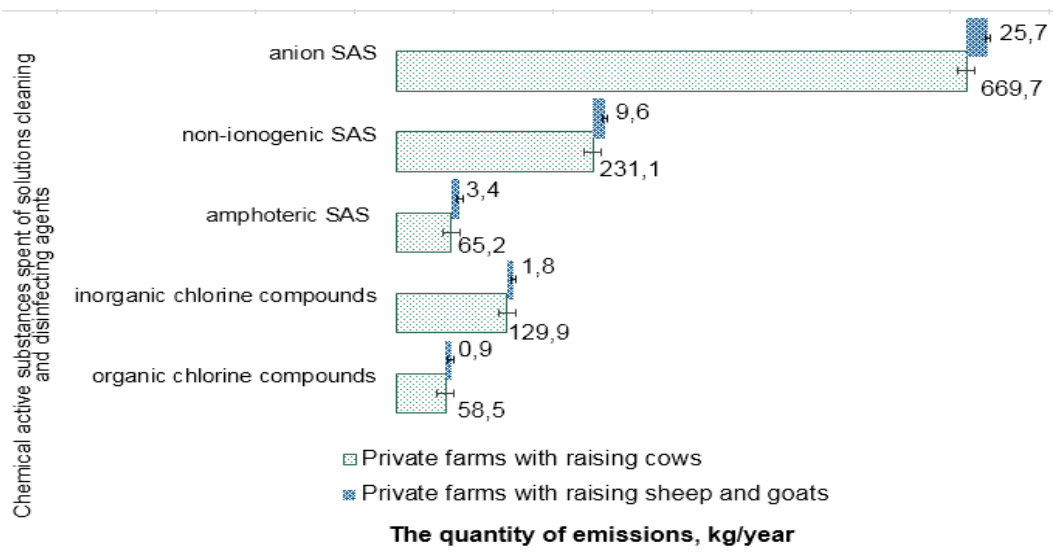

Figure 1. The intake of active substances spent of cleaning and disinfecting agents in soils after the sanitizing of milking machines and milk containers in private farms

In case of using in private farms with 238 cows and 264 sheep and goats with such agents as GALA for dishes, FAIRY juicy lemon, Pur Balsam, Pur Power Lemon, Chystyunya Lemon, Lemon Fresh, Origami Golden, Neochlor, Novochlor-Ekstra, Chlorantoyin and Dezactine most of all in soils the intake SAS that account for $88.6 \%$. To a lesser extent the intake inorganic and organic chlorine compounds which is $7.8 \%$ and $3.7 \%$ respectively.

We calculated the intake in soils spent of agents in private farms Ternopil, Ivano-Frankivsk and Chernivtsi regions with raising according to state statistics on 1 November $2017-230700$ cows and 87800 sheep and goats [1] (Figure 2). 


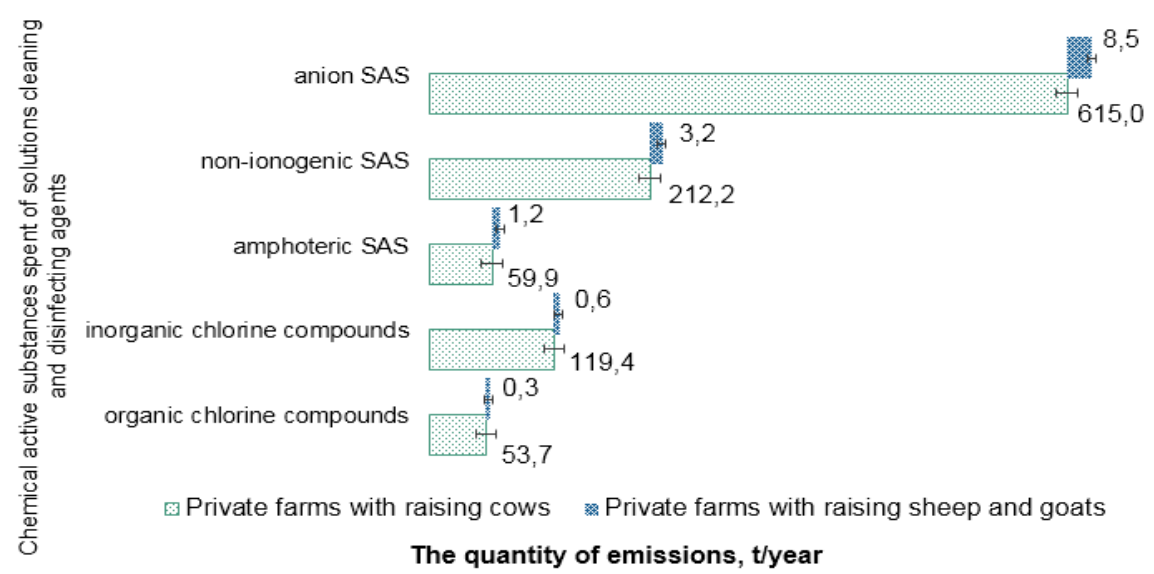

Figure 2. The intake of active substances spent of cleaning and disinfecting agents in soils in private farms Ternopil, Ivano-Frankivsk and Chernivtsi regions

In case of using of the above-mentioned agents in private farms Ternopil, Ivano-Frankivsk and Chernivtsi regions, the total in soils within a year intake $1074.0 \mathrm{t}$ of chemical active substances.

\section{Conclusion}

After realization of sanitizing of milking machine and containers in private farms Ternopil, Ivano-Frankivsk and Chernivtsi regions, within a year into the soil the intake such components cleaning and disinfecting agents how surface active substances $-900.0 \mathrm{t}$ and chlorine compounds $-174.0 \mathrm{t}$, which may result negatively influence of ecosystems.

Prospects of subsequent researches. Further detection and control environmentally hazardous cleaning and disinfecting agents in the dairy industry will allow reduce the negative impact on ecosystems.

\section{Bibliography}

1. The official site of State Statistics Service of Ukraine, available at: www.ukrstat.gov.ua.

2. Jones G.M. (2009). Cleaning and Sanitizing Milking Equipment. Publications (Virginia Cooperative Extension), 400-404:1-4. Available at: https://pubs.ext.vt.edu/404/404-400/404-400.html.

3. Gilbert P.H. (1982) The use of detergents and sanitizers in Dairy Farm Sanitation: an updated perspective. Journal of the South African Veterinary Association, 53(2):103-106.

4. Zhukorskyi O.M., Kryvokhyzha Ye.M. (2016) Ecological risks of using chemical sanitizing agents for milking machines and milk containers. Agricultural science and practice, 3 (3):12-16.

5. Bobyl'ova O.A., Gerasimova V.G., Snoz S.V., Shilina V.F. (2006) Voprosy bezopasnosti dlya zdorov'ya cheloveka tovarov bytovoy khimii pri provedenii gosudarstvennoy sanitarnoy epidemiologicheskoy ekspertizy [Problems of household chemical goods safety for human health during state sanitary-epidemiological expertise]. Sovremennye problemy toksikologii [Modern problems of toxicology], 4:38-43 [in Russian].

6. Belova V.I., Volkov Yu. P. (1991) Osnovnye napravleniya issledovaniy v razrabotke dezinfitsiruyushchikh sredstv [The main areas of research in the development of disinfectants]. Sb. n. tr. NII vaktsin i syvorotok. Nauchnye osnovy dezinfektsii i sterilizatsii [Collection of Scientific Papers Research Institute of Vaccines and Sera. Scientific basis disinfection and sterilization], Moscow, 13-18 [in Russian].

7. Lal H., Misra V., Viswanathan P.N., KrishnaMurti C.R. (1983) Comparative studies on ecotoxicology of synthetic detergents. Ecotoxicology and Environmental Safety, 7 (6):538-545.

8. Abel P.D. (1974) Toxicity of synthetic detergents to fish and aquatic invertebrates. Journal of Fish Biology, 6(3):279-298.

9. Azizullah A., Richter P., Ullah W., Ali l., Häder D.P. (2013) Ecotoxicity evaluation of a liquid detergent using the automatic biotest ECOTOX. Ecotoxicology, 22 (6):1043-1052. 
10. Gheorghe S., Lucaciu I., Grumaz R. (2011) Detergents legislative framework and ecotoxicological testing methodology. Journal of Environmental Protection and Ecology, 12 (3A):1525-1532.

11. Boillot C., Emmanuel E., Perrodin Y. (2006) Étude des effets combinés du glutaraldéhyde et des surfactants contenus dans les effluents hospitaliers vis-à-vis de Daphnia magna. Déchets. Sciences et Techniques, 42:22-28.

12. Emmanuel E., Blanchard J-M., Keck G., Vermande P., Perrodin Y. (2004) Toxicological effects of sodium hypochlorite disinfections on aquatic organisms and its contribution to AOX formation in hospital wastewater. Environment International, 30 (7):891-900. 